\title{
THE INTERNAL STRUCTURE AND ICE CRYSTALLOGRAPHY OF SEASONAL FROST MOUNDS
}

\author{
By W. H. POLLARD \\ (Department of Geography, University of Ottawa, Ottawa, Ontario K1N 6N5, Canada) \\ and $\mathrm{H}$. M. FRENCH \\ (Departments of Geography and Geology, University of Ottawa, Ottawa, Ontario K1N 6N5, Canada)
}

\begin{abstract}
Astract. The crystal character of the ice core within frost blisters supports the hypothesis that groundwater injection into residual zones of the active layer followed by rapid freezing is the primary growth mechanism for these features. The ice core is characterized by an upper zone of relatively small randomly arranged equigranular ice crystals which change with increasing depth to columnar anhedral crystals, commonly exceeding $200 \mathrm{~mm}$ in length, and with crystal diameters ranging between 25 and $35 \mathrm{~mm}$ Petrofabric analyses show that the $c$-axis orientations are normal to crystal elongations, with crystal growth along the basal plane in an $a$-axis direction. These observations eliminate ice segregation as a possible growth mechanism, thereby distinguishing seasonal frost mounds from palsas.
\end{abstract}

RÉsumÉ. Structure interne et pétrographie des cryolaccolithes. Les caractéristiques cristallographiques du noyau de glace des cryolaccolithes favorisent l'hypothèse que l'injection d'eau souterraine dans des zones résiduelles de la couche active, suivie d'une congélation rapide, est le mécanisme essentiel de leur croissance. Le noyau de glace est caractérisé par une couche supérieure de cristaux relativement petits, équigranulaires et orientés de manière aléatoire, passant en profondeur à une couche de cristaux columnaires de 25 à $35 \mathrm{~mm}$ de diamètre qui dépassent généralement $200 \mathrm{~mm}$ de long. Les axes optiques (c) sont

\section{INTRODUCTION}

Seasonal frost mounds are a group of ephemeral winter periglacial landforms with an internal structure that reflects a groundwater-injection origin. Previous studies in northern interior Yukon indicate that many mounds possess an ice core together with a water chamber, and that high hydraulic potentials are encountered during growth (e.g. Pollard and French, 1983, 1984). Although seasonal frost mounds have been reported from other Arctic and sub-Arctic regions (e.g. Leffingwell, 1919; Muller, 1945, p. 59-61; Academia Sinica, 1975; Van Everdingen, 1978, 1982; Frederking, 1979; French and Gilbert, 1982; Brown and others, 1983), there is a lack of information regarding their growth mechanisms. One possible approach is to describe their ice-crystal and gas-inclusion characteristics, since ice-fabric analysis can be used to infer freezing conditions which formed the ice (e.g. Andrews, 1962; Corte, 1962), particularly when fabrics show a preferred crystal orientation (e.g. Ketcham and Hobbs, 1967; Gell, 1978[a], [b]).

Occasionally, seasonal frost mounds are confused with perennial frost mounds such as palsas. The latter grow primarily by ice segregation (Zoltai and Tarnocai, 1971, Kershaw and Gill, 1979). Differentiation based upon internal structure and ice-core characteristics helps to clarify mound genesis.

\section{FIELD WORK}

On several occasions between August 1980 and March 1982 seasonal frost mounds of the blister type were sectioned in the North Fork Pass area, Yukon Territory, perpendiculaires à l'allongement, la croissance se faisant dans le plan de base, parallèlement à un axe $a$. Ces observations, éliminant la possibilité d'une croissance par ségrégation de glace, permettent de séparer, du point de vue génétique, les cryolaccolithes (frost-mounds) des "palsas".

ZUSAMMENFASSUNG. Die innere Struktur und Eiskristallographie von jahreszeitlichen Frostwällen. Die Art der Kristalle des Eiskerns in Frostblasen stützt die Theorie, dass das Eindringen von Grundwasser in Restzonen der aktiven Schicht, gefolgt von schnellem Gefrieren, der Hauptwachstumsmechanismus für diese Erscheinungen ist. Der Eiskern ist durch eine obere Zone mit relativ kleinen, zufällig angeordneten gleichkörnigen Eiskristallen gekennzeichnet, die sich mit wachsender Tiefe zu säulenförmigen, wasserfreien Kristallen, meist nicht länger als $200 \mathrm{~mm}$ und mit Durchmessern zwischen 25 und $35 \mathrm{~mm}$, verändern. Petrographische Analysen zeigen, dass die Orientierung der $c$-Achsen senkrecht zur Verlängerung der Kristalle steht, wobei das Kristallwachstum länge der Bosisebene in einer $a$-Achsenrichtung erfolgt. Diese Beobachtungen schliessen die Absonderung von Eis als möglichen Wachstumsmechanismus aus, wodurch eine Unterscheidung zwischen jahreszeitlichen Frostwällen und Palsas möglich wird.

Canada (Fig. 1). Ice samples were obtained using a chain-saw, ice-pick and an axe. Oriented blocks were taken from the ice core near the contact with overlying sediments and from the centre of the ice core. Samples were transported in freezer chests; temperatures were maintained below $-5^{\circ} \mathrm{C}$ at all times during transport and between $-10^{\circ}$ and $-15^{\circ} \mathrm{C}$ during storage. Petrographic analyses were performed on ice from four mounds. Thin sections were prepared using a band-saw and microtome, and hotplate, and standard universal stage techniques (Bader, 1951; Rigsby, 1951; Langway, 1958) were employed. Orientations were plotted on a Schmidt equal-area net with the lower hemisphere as the projection on which the $c$-axes are plotted.

\section{INTERNAL STRUCTURE}

With few exceptions, the frost blisters (Fig. 2a and b) are covered by a surface-vegetation mat which insulates the surface layers. Beneath, there is usually a thin $(10-50 \mathrm{~cm})$ layer of peat grading into organic-rich silt. The latter unconformably overlies a body of clear ice. Frequently, the ice appears layered, with bands of gas bubbles and, sometimes, sediment inclusions. In some frost blisters, the ice forms an epigenetic body unconformably overlying frozen ice-rich sediments. In others, cores consist of one or more layers of clear ice arched over a water-filled chamber. Typically, the thickness of the ice varies between 30 and $80 \mathrm{~cm}$ and the height of the chamber varies between 20 and $90 \mathrm{~cm}$. Gas inclusions range from small spherical bubbles to vertically oriented elongated tubular bubbles, sometimes $1 \mathrm{~cm}$ in diameter and $3-4 \mathrm{~cm}$ long. 


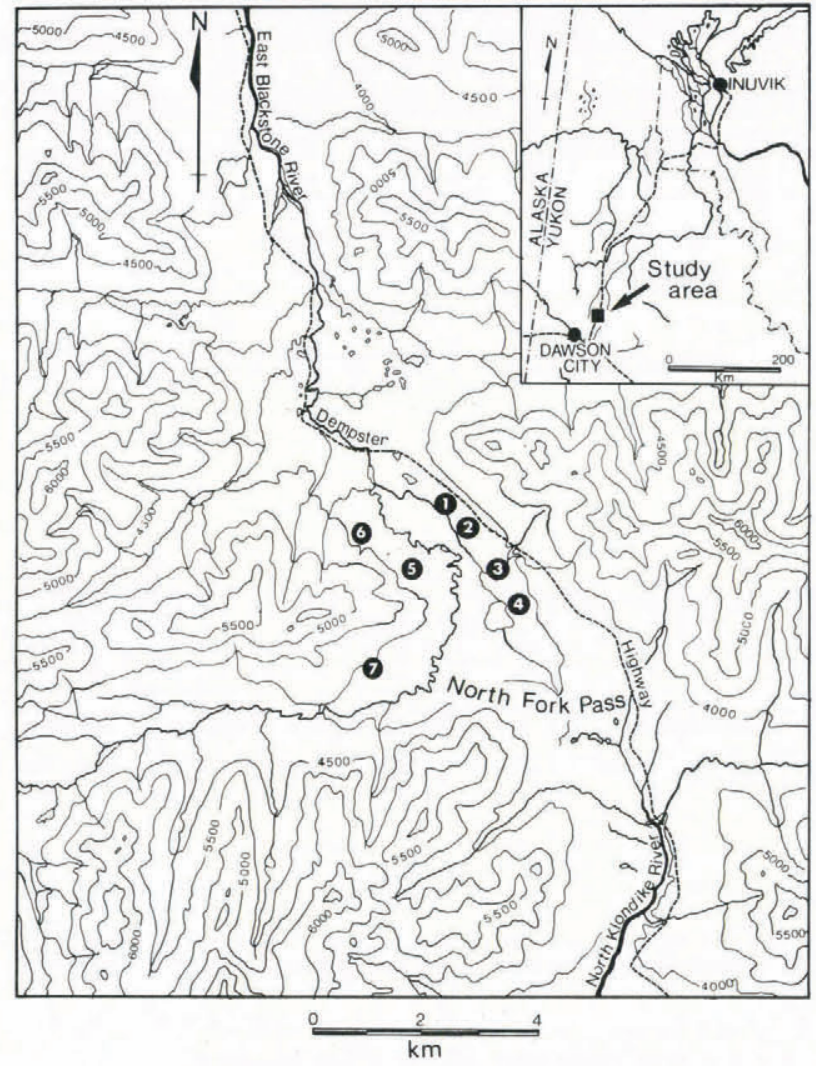

Fig. 1. Location map of the North Fork Pass area, northern interior Yukon, showing areas of seasonal frost-mound activity.

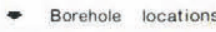

\section{a}
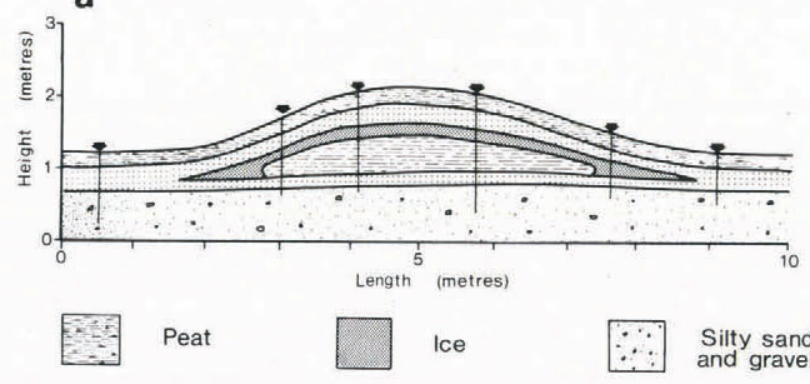

Organic silt Water-filled chamber

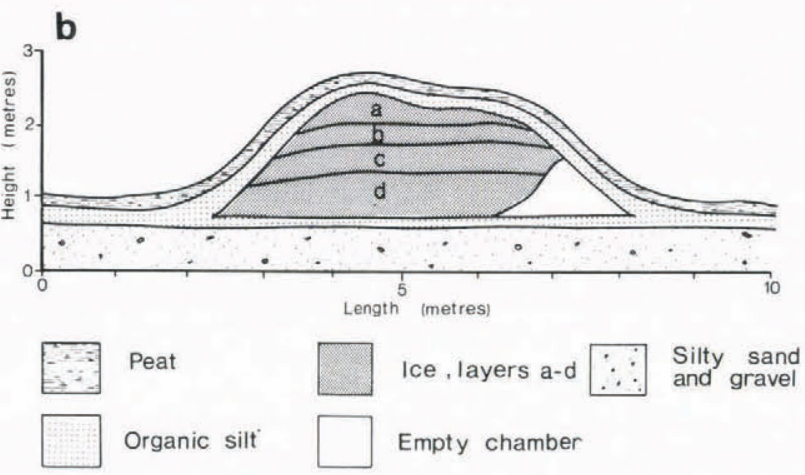

Fig. 2. Sections through two frost blisters in the North Fork Pass area, northern interior Yukon. (a) Observed in September 1980, and (b) based on drilling data obtained in September 1981.

\section{ICE CHARACTERISTICS}

Information concerning growth processes can be obtained by examination of (a) gas-inclusion characteristics, and (b) ice texture and petrofabrics of the ice core

\section{Inclusions}

During freezing, most impurities are rejected from solid solution. One type of solute rejected is that which forms gas bubbles. The occurrence of gas inclusions in bubble-rich layers and as single-bubble trains has been described in massive ice (e.g. Mackay, 1971; Gell, unpublished) and in ice-lens ice (e.g. Gold, 1957, Penner, 1971). The range in bubble size, shape, orientation, and layering characteristics is a function of the freezing conditions under which the ice formed and may be used as an indicator of both freezing rate and direction.

Typically, gas bubbles present within the ice core of those seasonal frost mounds which have been investigated in the field occur within distinct bands parallel to the mound surface. Bubble size ranges from 1 to $9 \mathrm{~mm}$ in diameter Also present are filament-like bubbles and bubbles that widen downwards into bulbous shapes (Fig. 3). According to Gell (unpublished, p. 48-49), this type of inclusion occurs along crystal boundaries and provides a useful "way-up" indicator. Where bubble concentrations are high, the ice takes on a milky appearance. Usually, the bubbles, between 1 and $3 \mathrm{~mm}$ in diameter, are either spherical and/or oval in shape, and are arranged into either vertical bubble trains or, occasionally, long filaments. Bubbles of this nature form when water is changed to ice. If the rate of rejection is greater than the rate at which the gas molecules diffuse from the interface, the water adjacent to the interface will become saturated and air bubbles can then nucleate. In all observed cases, bubble elongation is normal to the direction of compositional layering, and parallel to the freezing direction and crystalline basal plane.

\section{Texture and fabric}

The main ice body of each of the mounds examined is composed of large elongated crystals which grow parallel to the freezing direction. Intercrystalline melting of this ice produces the distinct "candled" appearance widely reported in melting lake ice or river ice. In detail, there is a texture gradation within the ice core, reflecting rapid freezing at the sediment contact and slower freezing in the middle of the core. This results in a zone of small, randomly arranged, equigranular ice crystals from which the main body of water gradually froze into long columnar crystals. Gas inclusions in this zone are small and spherical in shape. At depth, within the ice core, large vertically oriented tubular bubbles occur predominantly along vertical grain boundaries.

Vertical and horizontal thin sections from one frost blister at depths of 7 and $40 \mathrm{~cm}$ below the upper sediment

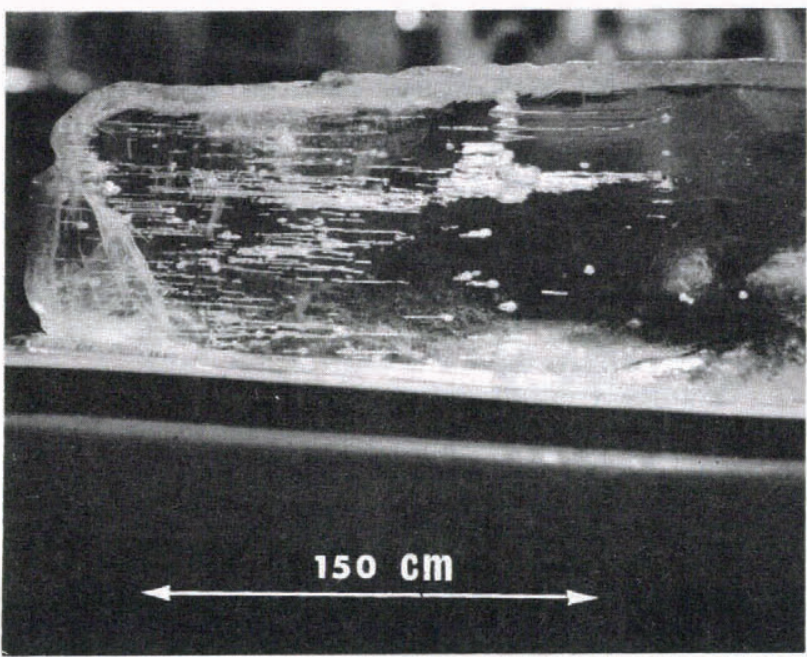

Fig. 3. Photograph under plane light of a large ice block from a frost blister in the North Fork Pass area. 

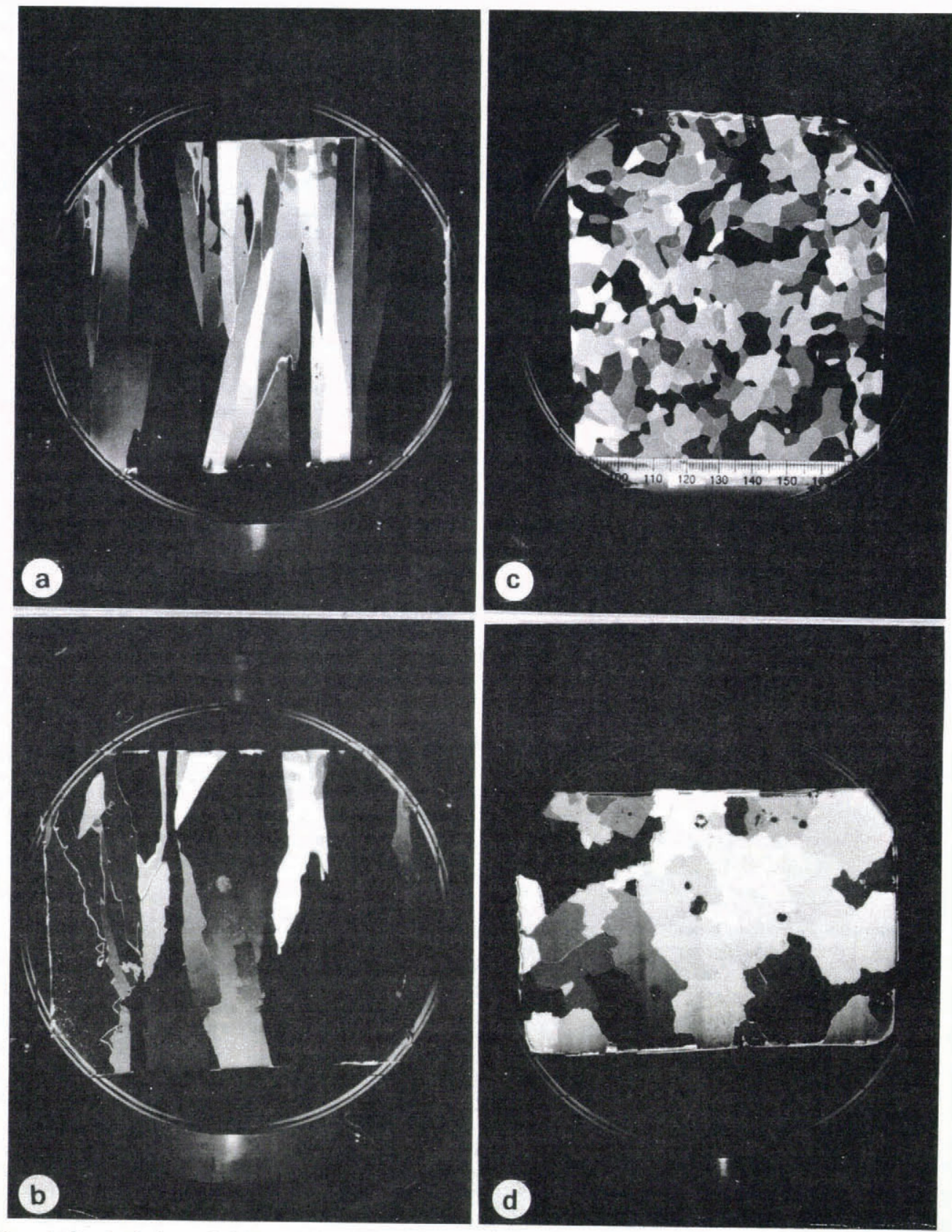

Fig. 4. Vertical ( $a$ and $b$ ) and horizontal ( $c$ and $d$ ) thin sections of frost-blister ice at depths of

$7 \mathrm{~cm}(a$ and $c)$ and $40 \mathrm{~cm}(b$ and $d)$. North Fork Pass area, northern interior Yukon.

contact (Fig. 4) illustrate the gradations in crystal texture. At $7 \mathrm{~cm}$ depth, narrow columnar crystals are clearly distinguishable, crystal diameters range from 2 to $15 \mathrm{~mm}$, vertically oriented crystals range from 30 to $90 \mathrm{~mm}$ in length, and crystal shape is predominantly anhedral with straight sides. At $40 \mathrm{~cm}$ depth, the columnar texture is much better defined, crystal diameters of $25-35 \mathrm{~mm}$ are common, and column lengths of ten exceed $200 \mathrm{~mm}$.

Petrofabric analyses further illustrate the gradation in texture with depth within the ice core. In contrast to an upper zone (Fig. 5a), where the crystal lattice is characterized by a rather more random pattern of $c$-axis orientations, the main ice body is characterized by a preferred distribution of $c$-axis orientations (Fig. 5b). The observed lattice orientation where vertically oriented columnar ice crystals have $c$-axis orientations normal to crystal elongation is one of the three common polycrystalline textures identified by Glen (1974). According to this author, this petrofabric is characteristic of the rapid growth of ice in bulk water with crystal growth along the basal plane in $a$-axis directions.

\section{Multi-year growth}

Where a seasonal frost mound survives intact into a second winter season, it may generate a new mound which may grow either as an appendage to the first mound or engulf the older feature. The ice cores of such mounds exhibit ice relationships not observed in single-year frost mounds.

For example, one mound, which formed in the 1979-80 winter and subsequently doubled in height and length in the 1980-81 winter showed four well-developed ice layers, each separated by distinct unconformities (Fig. 6). The sharpest corresponded with the two ice lenses that formed the upper part of the core. Within the contact was a thin band of fine sediment.

In all likelihood, the upper ice layer represented the remains of the ice core formed during the 1979-80 winter. If correct, the irregular upper contact is a thaw unconformity since, during the previous summer, the mound partially collapsed. It follows that the lower contact represents the boundary between ice of two different years. During growth in $1980-81$, the existing ice was heaved 

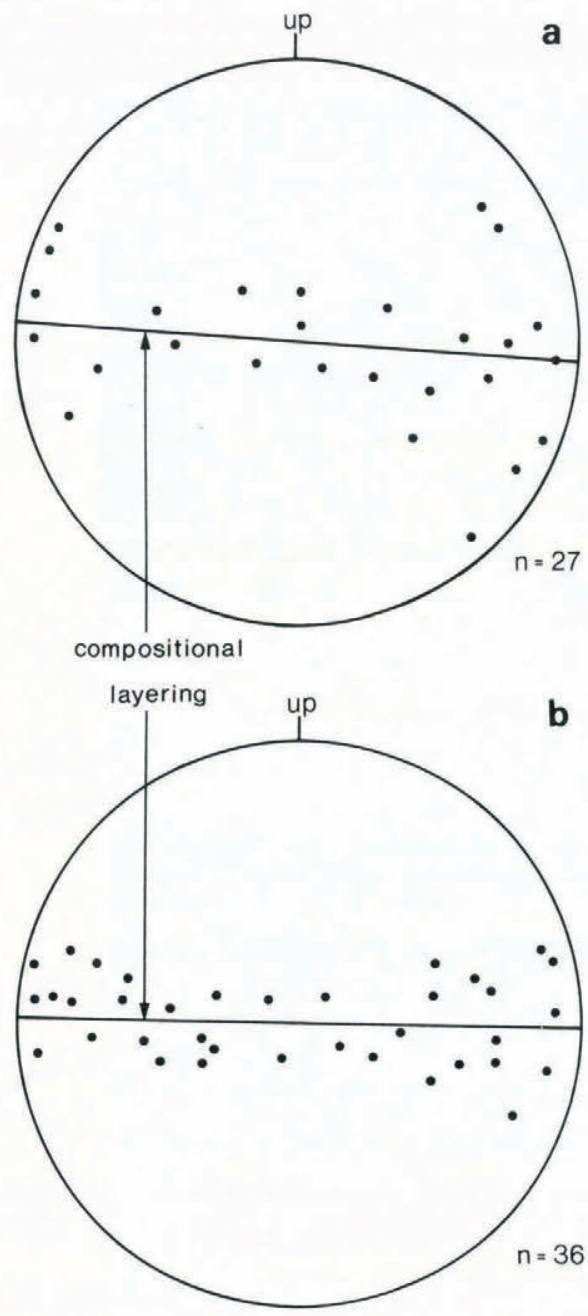

Fig. 5. Petrofabric diagrams for frost-blister ice, North Fork Pass area, based on crystal orientations of vertical thin sections from depths of (a) $7 \mathrm{~cm}$, and (b) 20-40 cm. The horizontal line represents the plane of compositional layering. Note the preferred distribution of c-axis orientations at depth which forms a girdle around the horizontal plane normal to the crystal elongation.
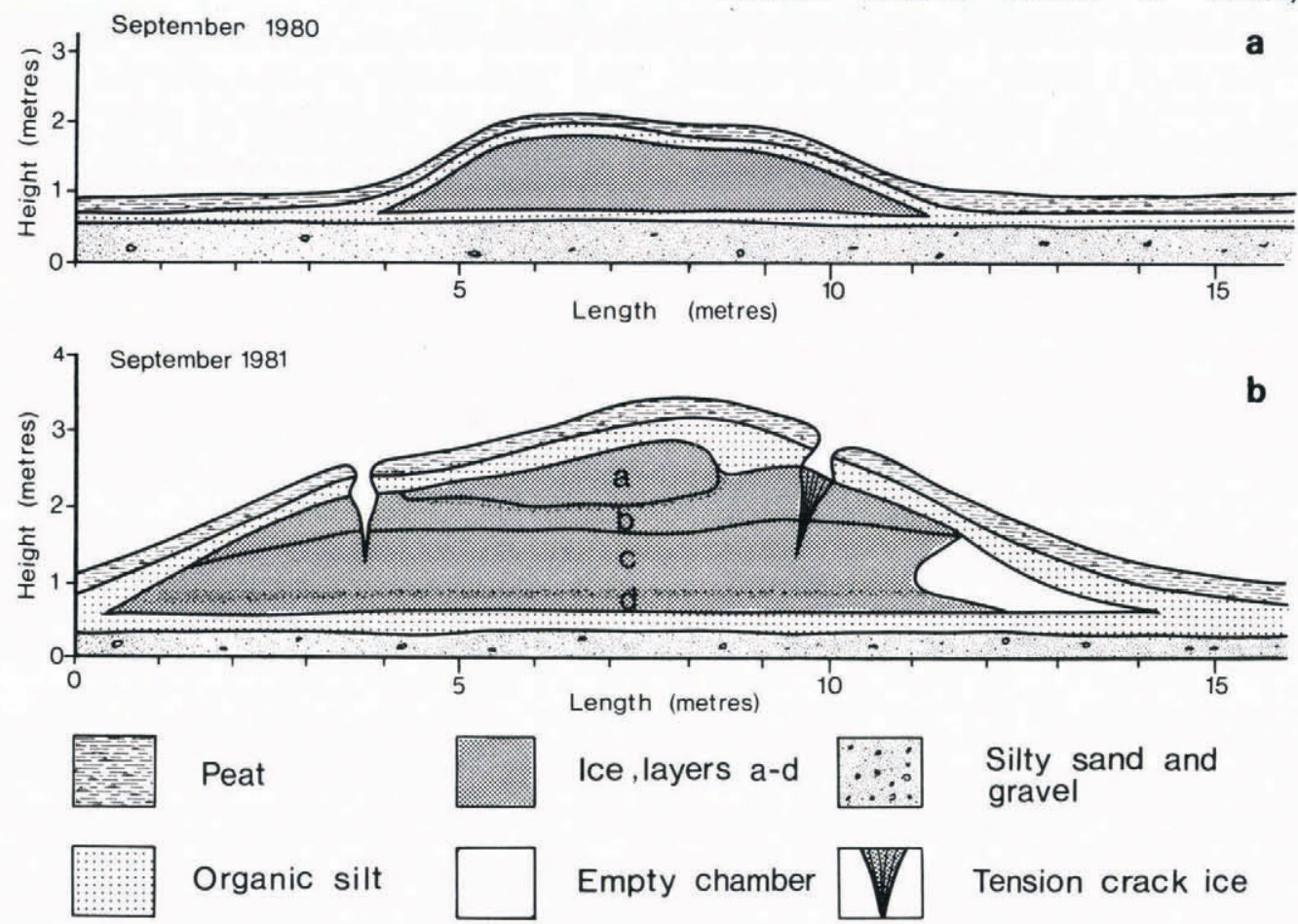

Fig. 6. Vertical cross-sections through frost blister 1-4, North Fork Pass area, based on (a) coring performed in September 1980, and (b) an excavated section observed in September 1981. upward by injection of groundwater.

This interpretation is supported by both crystal fabrics and gas-inclusion patterns. With respect to gas inclusions (Fig. 7a), small spherical gas bubbles occur in the upper part of the ice core, while lower down the bubbles are larger and form trains parallel to the earlier direction of ice growth. The trains are oriented at angles of $25-35^{\circ}$ from the vertical and terminate abruptly at the lower contact with the younger ice. Immediately beneath the contact, small spherical bubbles (less than $2 \mathrm{~mm}$ in diameter) form vertically aligned bubble trains up to $20 \mathrm{~mm}$ long.

Crystal textures show a similar pattern (Fig. $7 \mathrm{~b}$ and c). The older ice has a coarse columnar texture typical of injection ice observed in other mounds. However, crystal long axes are oriented $25-30^{\circ}$ from the vertical as a result of heaving during 1980-81. Petrofabrics for the older ice also show a wider distribution of $c$-axis orientations than for the ice at depth. In all probability the slightly modified crystal structure and matrix orientation resulted from the thermal and tensile stresses generated during the 1980-81 period of reactivation.

\section{CONCLUSIONS}

The ice cores of seasonal frost mounds occurring in the North Fork Pass area, interior Yukon, exhibit a crystal structure which indicates groundwater injection into the active layer, followed by downward freezing, as the primary growth mechanism. Typically, the main body of ice is composed of large columnar anhedral crystals with diameters ranging between 25 and $35 \mathrm{~mm}$, and lengths commonly exceeding $200 \mathrm{~mm}$. Petrofabric analyses show that $c$-axis orientations are normal to the long direction of crystals and that crystal growth occurred parallel to the basal plane in an $a$-axis direction. Where seasonal frost mounds experience multi-year growth, ice-fabric analysis provides a means of differentiating between younger and older ice. The technique is also useful in differentiating seasonal frost mounds from perennial forms, such as palsas, where ice segregation rather than injection is the primary mechanism.

\section{ACKNOWLEDGEMENTS}

Research was supported by the Natural Sciences and Engineering Research Council (grant A8367 to H.M. French) and the University of Ottawa Northern Research Group (W.H. Pollard). The authors wish to acknowledge Dr L. Gold, Associate Director, Division of Building Research, National Research Council of Canada, Ottawa, for 

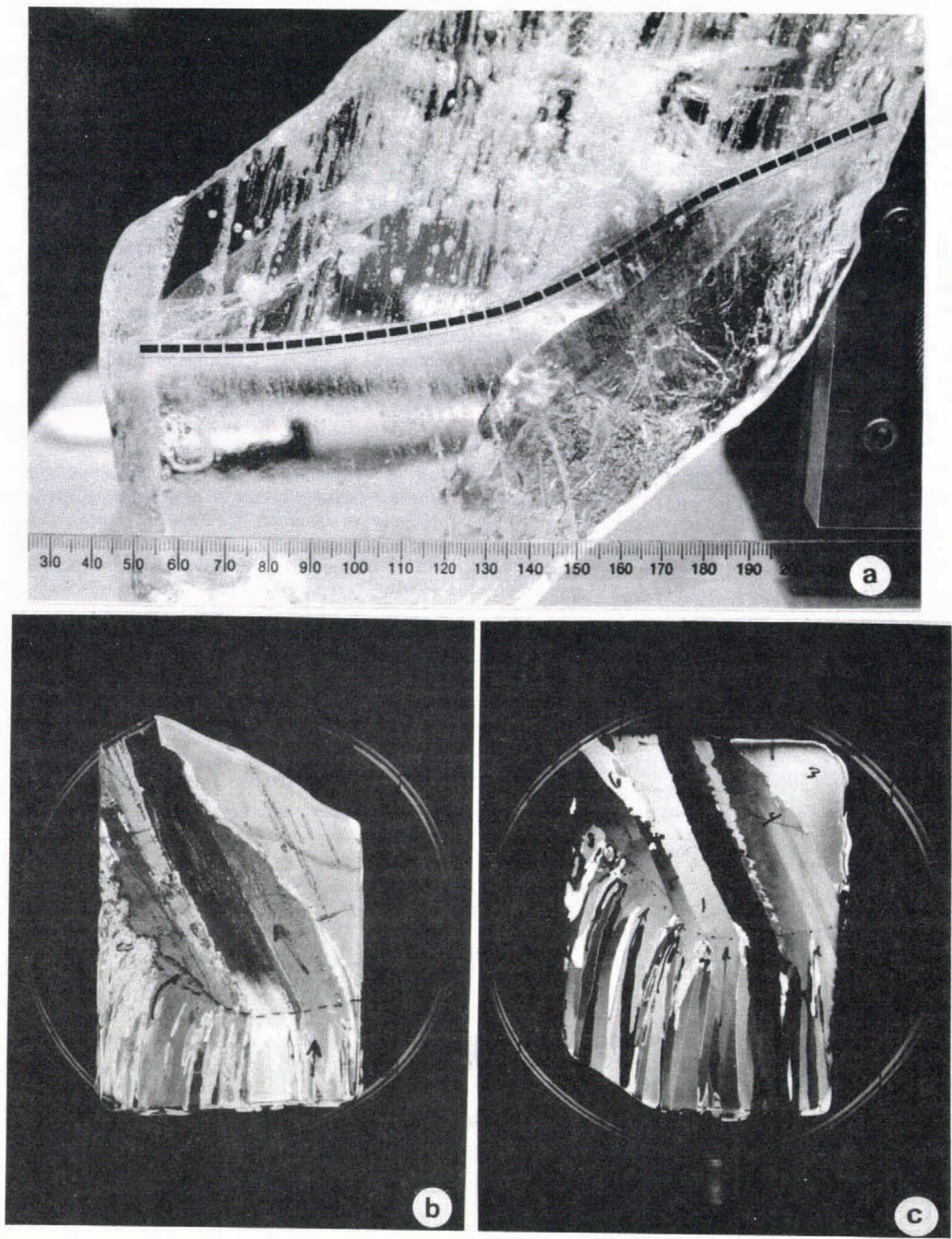

Fig. 7. Ice-core characteristics from a seasonal frost mound which experienced multi-year growth. (a) Ice sample showing contact between first-and second-year ice, and gas-inclusion pattern. Note variation in direction and pattern of gas bubb!es. (b) and (c) Thick (b) and thin (c) sections of ice sample $A$ viewed with cross-polarized light. Both show the relationship between the gas-bubble patiern and ice texture along the contact between first-and second-year ice.

permission to use their cold-room facilities, and $\mathrm{Dr} R$. Frederking and Dr N. Sinha (National Research Council of Canada), for helpful comments during ice-fabric analysis.

\section{REFERENCES}

Academia Sinica. 1975. Permafrost. Lanchou, China, Academia Sinica. Research Institute of Glaciology, Cryopedology and Desert Research. (National Research Council of Canada. Canada Institute for Scientific and Technical Information. Technical Translation 2006, 1981.)

Andrews, J.T. 1962. Variability of lake ice growth and quality in the Schefferville region, central Labrador-Ungava. Journal of Glaciology, Vol. 4, No. 33, p. 337-47.

Bader, H. 1951. Introduction to ice petrofabrics. Journal of Geology, Vol. 59, No. 6, p. 519-36.
Brown, J., and others. Observations on ice-cored mounds at Sukakpak Mountain, south central Brooks Range, Alaska, by J. Brown, F. Nelson, B. Brockett, S.I. Outcalt, and K.R. Everett. Proceedings of the Fourth International Conference on Permafrost, July 17-22, 1983, Fairbanks, Alaska. Washington, D.C, National Academy Press, Vol. 1, p. 91-96.

Corte, A.E. 1962. Relationship between four ground ice patterns, structure of the active layer, and type and distribution of ice in the permafrost. U.S. Cold Regions Research and Engineering Laboratory. Research Report 88.

Frederking, R.M.W. 1979. Rupture of an ice mound near Cape Dorset, N.W.T. Canadian Geotechnical Journal, Vol. 16, No. 3, p. 604-09.

French, H.M., and Gilbert, R. 1982. Periglacial phenomena near Churchill, Manitoba. Naturaliste Canadien, Vol. 109, No. 3 , p. 433-44 
Gell, W.A. 1978[a]. Fabrics of icing-mound and pingo ice in permafrost. Journal of Glaciology, Vol. 20, No. 84, p. 563-69.

Gell, W.A. 1978[b]. Ice-wedge ice, Mackenzie Delta-Tuktoyaktuk Peninsula area, N.W.T., Canada. Journal of Glaciology, Vol. 20, No. 84, p. 555-62.

Gell, W.A. Unpublished. Underground ice in permafrost, Mackenzie Delta-Tuktoyaktuk Peninsula, N.W.T. [Ph.D. thesis, University of British Columbia, 1976.]

Glen, J.W. 1974. The physics of ice. CRREL Monograph (Hanover, NH) II-C2a.

Gold, L. 1957. A possible force mechanism associated with freezing of water in porous materials. Bulletin. Highway Research Board 168, p. 65-73.

Kershaw, G.P., and Gill, D. 1979. Growth and decay of palsas and peat plateaus in MacMillan Pass-Tsichu River area, Northwest Territories, Canada. Canadian Journal of Earth Sciences, Vol. 16, No. 7, p. 1362-74.

Ketcham, W.M., and Hobbs, P.V. 1967. The preferred orientation in growth of ice from the melt. Journal of Crystal Growth, Vol. 1, No. 5, p. 263-70.

Langway, C.C., jr. 1958. Ice fabrics and the universal stage. U.S. Snow, Ice and Permafrost Research Establishment. Technical Report 62.

Leffingwell, E. de K. 1919. The Canning River region, northern Alaska. United States Geological Survey. Professional Paper 109.

Mackay, J.R. 1971. The origin of massive icy beds in permafrost, western Arctic coast, Canada. Canadian Journal of Earth Sciences, Vol. 8, No. 4, p. 397-422.
Muller, S.W. 1945. Permafrost or permanently frozen ground and related engineering problems. Washington, DC, U.S. Army. Military Intelligence Division. (Special Report. Strategic Engineering Study, No. 62.)

Penner, E. 1971. Ice-grain structure and crystal orientation in an ice lens from Leda clay. Geological Society of America. Bulletin, Vol. 72, No. 10, p. 1575-77.

Pollard, W.H., and French, H.M. 1983. The occurrence of seasonal frost mounds, North Fork Pass, Ogilvie Mountains, Yukon Territory. Proceedings of the fourth International Conference on Permafrost, July 17-22, 1983, Fairbanks, Alaska. Washington, DC, National Academy Press, Vol. 1, p. 1000-04.

Pollard W.H., and French, H.M. 1984. The groundwater hydraulics of seasonal frost mounds, North Fork Pass, Yukon Territory. Canadian Journal of Earth Sciences, Vol. 21, No. 10, p. 1073-81.

Rigsby, G.P. 1951. Crystal fabric studies on Emmons Glacier, Mount Rainer, Washington. Journal of Geology, Vol. 59, No. 6, p. 590-99.

Van Everdingen, R.O. 1978. Frost mounds at Bear Rock, near Fort Norman, Northwest Territories, 1975-1976. Canadian Journal of Earth Sciences, Vol. 15, No. 2, p. 263-76.

Van Everdingen, R.O. 1982. Frost blisters of the Bear Rock spring area near Fort Norman, N.W.T. Arctic, Vol. 35, No. 2, p. 243-65.

Zoltai, S.C., and Tarnocai, C. 1971. Properties of a wooded palsa in northern Manitoba. Arctic and Alpine Research, Vol. 3, No. 2, p. 115-29. 